\title{
PREFACE FROM \\ THE 1974 EDITION
}

To many Californians, the wealth of the state lies in its gold, its petroleum, its timber, or its fertile valleys. To those of us who are amateur or professional botanists, or who simply enjoy "plant watching," the riches of California are also reflected in the diversity of wildflowers, shrubs, and trees that occur throughout the state. California is isolated from the rest of North America by deserts or mountains that have allowed the development within its boundaries of one of the most varied floras that occurs anywhere on earth. The plant cover ranges from the forests of the northern coast and the mountain slopes, to the woodlands and scrublands of the foothills and deserts, to the grasslands of the valleys. Our plants range in size from the stately Coast Redwoods of the fog-shrouded coast to the minute belly plants of the southern deserts, and in age from the venerable four-thousand-year-old Bristlecone Pines to the diminutive ephemeral annuals whose life span can be counted in weeks.

This small book introduces you to the plant life of California and tells you something of how plants are grouped into communities and what environmental influences determine the pattern of distribution of these communities in the state. It also discusses the origin of our flora, how plants are adapted to the diverse climates of the state, and how they respond to 
forest and chaparral fires, to unusual soils, to man, and to each other.

The contents of this book are adapted from a syllabus that I wrote for an Independent Study course developed for the University of California, Berkeley. Because most of my botanizing has been in northern California, the contents of the book are perhaps unevenly weighted toward this portion of the state. Drafts of portions of the manuscript were read by L. R. Heckard, J. R. McBride, D. R. Parnell, and a few other friends and colleagues to whom I am indebted for helpful suggestions. I am also grateful to S. C. H. Barrett, R. Benseler, S. Carlquist, D. Hafner, L. M. Moe, and A. C. Smith for allowing me to reproduce their slides, to C. Mentges for executing the line drawings, and to P. Watters for her assistance in preparing the manuscript. Several of the color illustrations have been taken from the slide collection of the Jepson Herbarium, University of California, Berkeley. I am also indebted to my students, who have proven time and again that there is still a great deal that I have to learn about California plants, and that most of this will be gained by studying the plants themselves and not what is written about them in books.

Map 1. Major topographical features of California. The portion of the state in the California Floristic Province is to the coastward side of the hatched line.

Robert Ornduff

June 1974 